\title{
PARADIGME BIBLICE ALE ASCULTĂRII
}

\author{
Protos. asist. dr. Hrisostom CIUCIU \\ Facultatea de Teologie Ortodoxă „Dumitru Stăniloae” din Iași
}

\begin{abstract}
The present work, which belongs to the biblical spirituality domain, aims to extract some characteristics about obedience from a few biblical fragments that, although they do not directly refer to obedience, nevertheless constitute paradigms for a much better understanding of obedience and a real support of practicing it. For this reason, we have called these fragments that we will analyze "biblical paradigms". Being a work of biblical spirituality, the emphasis will not be placed on biblical study (in the sense of biblical exegesis), but on the spiritual hermeneutics of these biblical fragments, whose main purpose is the spiritual life, in a practical way of speaking.
\end{abstract}

Keywords: obedience, biblical paradigms, spiritual obedience, spiritual hermeneutics.

În prezenta lucrare vom aborda ascultarea în funcție de „paradigmele biblice" care se referă la aceasta. Nu vom încerca să identificăm și să ne ocupăm de toate locurile din Sfânta Scriptură care tratează problema ascultării (adică ,,trimiterile biblice”), ci ne vom referi doar la câteva dintre referatele biblice, pe care le-am numit „paradigme biblice”, adică acele locuri din Sfânta Scriptură care, chiar dacă nu vorbesc direct despre ascultare, se referă la unele aspecte importante ale acesteia, luminându-ne înțelesul ei. Dată fiind importanța practică a acestor aspecte sau sensuri ale ascultării, am numit aceste locuri paradigme sau modele.

\section{Ascultarea lui Avraam (Facerea 12-22)}

Începem acest șir al paradigmelor biblice cu ascultarea lui Avraam, căci el este Părintele tuturor neamurilor, iar prin Isaac este considerat și Părintele tuturor celor care se mântuiesc, de aceea noi suntem moștenitorii lui sau mai bine zis ai Harului pe care el l-a primit de la Dumnezeu pentru noi: De aceea (moștenirea făgăduită) este din credință, ca să fie din har și ca făgăduința să rămână sigură 
pentru toți urmașii, nu numai pentru toți cei ce se țin de lege, ci și pentru cei ce se țin de credința lui Avraam, care este părinte al nostru al tuturor (Romani 4, 16).

Este foarte important să subliniem de la bun început un lucru ce va funcționa pentru noi în studiul de față ca un fir roșu pe care urmărindu-l, vom înțelege mult mai bine și mai nuanțat aspectul ascultării pe care dorim să-l întărim prin această paradigmă biblică. Este vorba despre faptul că făgăduința lui Dumnezeu, care i-a fost dată lui Avraam - și prin el și nouă - se transmite doar prin Isaac (care este rodul sau împlinirea - în mod vizibil - făgăduinței dumnezeiești), nu și prin Ismael (cf. Facerea 21, 12: Dumnezeu însă a zis către Avraam: «Să nu ți se pară grele cuvintele cele pentru prunc și pentru roabă; toate câte-ți va zice Sarra, ascultă glasul ei; pentru că numai cei din Isaac se vor chema urmașii tăi»).

Acest lucru este relevant în principal pentru că arată faptul că moștenirea nu este doar un rezultat automat al descendenței familiale, ci ea arată de fapt legătura paternal-filială care-și păstrează continuitatea prin ascultare, care trebuie făcută în mod deplin și, mai ales, în deplină libertate (Ismael era fiu din roaba Agar!). Dumnezeu întărește făgăduința pe care i-a dat-o lui Avraam, transferându-i-o lui Isaac, subliniind că ascultarea tatălui său Avraam este aceea care menține de fapt legătura dintre Dumnezeu și urmașii lui. Desigur, se subînțelege faptul că și urmașii lui Isaac vor putea primi la rândul lor binecuvântarea lui Dumnezeu, rămânând în legătură cu El, în măsura în care sunt ascultători: Locuiește în țara aceasta și Eu voi fi cu tine și te voi binecuvânta, că ție și urmașilor tăi voi da toate ținuturile acestea și-Mi voi împlini jurământul cu care M-am jurat lui Avraam, tatăl tău. Voi înmulți pe urmașii tăi ca stelele cerului și voi da urmașilor tăi toate ținuturile acestea; și se vor binecuvânta întru urmașii tăi toate popoarele pământului, pentru că Avraam, tatăl tău, a ascultat cuvântul Meu și a păzit poruncile Mele, povețele Mele, îndreptările Mele și legile Mele! (Facerea 26, 3-5).

Sfântul Apostol Pavel vede aici mai mult decât o simplă transmitere condiționată de supunere. El, privind lucrurile în mod tainic, duhovnicesc, arată că în ascultarea desăvârșită - aceea pe care doar Hristos o face cu adevărat - se poate înțelege, trăi și păstra Taina viețuirii în Hristos. Doar în unire cu Hristos, prin ascultarea pe care o facem $c a$ El, rămânem în relație cu Dumnezeu și putem să ne numim fii ai Lui: $C a$, prin Hristos Iisus, să vină la neamuri binecuvântarea 
lui Avraam, ca să primim, prin credință, făgăduința Duhului... Făgăduințele au fost rostite lui Avraam și urmașului său. Nu zice: «și urmașilor»ca de mai mulți-, ci ca de unul singur: «și Urmașului tău», Care este Hristos... Căci dacă moștenirea este din Lege, nu mai este din făgăduință, dar Dumnezeu i-a dăruit lui Avraam moștenirea prin făgăduință... Iar dacă voi sunteți ai lui Hristos, sunteți deci urmașii lui Avraam, moștenitori după făgăduință (Galateni 3, 14, 16, 18, 29).

Prin Avraam binecuvântarea lui Dumnezeu s-a împărtășit tuturor popoarelor. Aceasta arată, pe de o parte, puterea și măreția ascultării, iar, pe de altă parte, subliniază universalitatea legământului făcut de Dumnezeu cu Avraam. Sfântul Ioan Gură de Aur arată importanța covârșitoare a vieții lui Avraam pentru toți oamenii spunând: „Ca un lanț de aur, așa găsim viața lui în dumnezeieștile Scripturi! De fiecare dată este arătată mai întâi filosofia lui, urmată îndată și de răsplata cea de la Dumnezeu... E în stare dreptul acesta să ne învețe pe noi toți să pornim cu râvnă spre luptele virtuții, având încredere în răsplata cea de sus" ${ }^{1}$. Astfel, relația dintre Dumnezeu și Avraam în particular se extinde la relația dintre Dumnezeu și om în general, această relație având drept fundament ascultarea.

\section{Întâlnirea dintre Avraam şi Melchisedec (Facerea 14, 18-20)}

Primul moment din viața lui Avraam, la care ne vom opri pentru a extrage o învățătură despre ascultare, este întâlnirea lui cu Dreptul Melchisedec despre care aflăm în Facerea 14, 18-20 și despre care vorbește și Sfântul Apostol Pavel în Epistola către Evrei (Evrei 6-7). Aici aflăm despre un lucru mai puțin obișnuit și greu de înțeles, anume de faptul că Avraam - cel care a primit făgăduința (și de la care și prin care suntem și noi moștenitori ai aceleiași făgăduințe) și din coapsa căruia toți își trag seminția - îi aduce zeciuială lui Melchisedec, primind binecuvântare de la acesta din urmă. Sfântul Pavel subliniază aici faptul că Melchisedec s-a arătat a fi mai mare decât Avraam (Evrei 6-7), prefigurându-L pe Hristos. Melchisedec a reușit să facă ceea ce n-a putut Avraam, anume să

${ }^{1}$ Sfântul Ioan Gură de Aur, Scrieri, partea a II-a, în col. „Părinți și Scriitori Bisericești", vol. 22, traducere, introducere, indici și note de pr. Dumitru Fecioru, EIBMBOR, București, 1989, p. 29. 
ne introducă dincolo de catapeteasmă, în Sfânta Sfintelor ( $c f$. Evrei 6, 19-20). Comparându-i pe Avraam și Melchisedec, Sfântul Pavel ne aduce înainte de fapt două tipuri de preoție, cea după Lege (a lui Aaron și Levi, care erau amândoi „în coapsa lui Avraam” cf. Evrei 7,10$)$ și cea „după rânduiala lui Melchisedec" (cf. Evrei 7, 17; Psalmi 109, 4), în care ultima este superioară celei dintâi, căci s-a făcut nu după legea unei porunci trupești, ci cu puterea unei vieți nepieritoare (Evrei 7, 16).

S-ar părea că, din punct de vedere al ascultării, suntem aici într-un impas, deoarece Avraam este considerat a fi modelul ascultătorului. Pentru a înțelege lucrurile avem nevoie să ținem cont de două aspecte pe care le subliniază Sfântul Pavel: 1. Se referă în special la preoție; 2 . Avem aici o deosebire între cele două preoții, care face trimitere la deosebirea dintre trup și suflet, sau mai bine zis dintre trupesc și duhovnicesc. Preoția înseamnă în primul rând jertfă și ne referim aici la jertfa de mijlocire înaintea lui Dumnezeu. Prin urmare comparația care se face aici este între jertfa (sau preoția) lui Avraam - care ni s-a transmis și nouă prin rânduiala preoției levitice - și jertfa lui Melchisedec - care a prefigurat-o pe aceea a lui Hristos. Prima este trupească, și prin urmare nedesăvârșită, iar a doua este duhovnicească, desăvârșită. De aceea ascultarea este și trebuie să fie înțeleasă mai ales ca pe o jertfă și nu ne referim aici doar la acea jertfă de sine care este numită și mucenicie albă sau nesângeroasă, ci la jertfa aceea care mijlocește iertarea celorlalți (cf. Psalmi 36, 25-26: tânăr am fost și am îmbătrânit și n-am văzut pe cel drept părăsit, nici seminția lui cerând pâine; Toată ziua dreptul miluiește și împrumută și seminția lui binecuvântată va fi).

De aici tragem o primă concluzie și anume că ascultarea trebuie făcută „după rânduiala lui Hristos”, adică duhovnicește, nu trupește. Aceasta înseamnă că nu atât supunerea este cea care contează, ci acea ascultare care te face fiu al lui Dumnezeu. De asemenea, Melchisedec se arată a fi deasupra lui Avraam și prin deplina dăruire de sine, dăruire care este îngemănată cu deplina lepădare de tot ceea ce este lumesc, căci el, Melchisedec, nu avea nici o legătură pământească, fiind, așa după cum îl numește Sfântul Pavel, fără tată, fără mamă, fără spiță de neam, neavând nici început al zilelor, nici sfârșit al vieții, ci, asemănat fiind Fiului lui Dumnezeu și, de aceea, el rămâne preot pururea (cf. Evrei 7, 3). 
Tot legat de aceasta trebuie să mai subliniem și un alt aspect al ascultării, legat de ierarhia bisericească. Zeciuiala adusă de Avraam lui Melchisedec și binecuvântarea pe care a primit-o în schimb, arată că toate rânduielile bisericești (care sunt prefigurate aici de Aaron și Levi) trebuie subsumate celor duhovnicești. Aceasta înseamnă nu numai că toate trebuie făcute și înțelese în mod duhovnicesc, ci și că autoritatea ultimă în Biserică nu trebuie aflată în ierarhia privită ca instituție. Autoritatea ultimă în Biserică nu este reprezentată de cel care este cel mai înalt în rang, ci de Părintele duhovnicesc. Așa a funcționat de mii de ani Biserica Ortodoxă și așa funcționează și astăzi. Orice credincios al Bisericii, fie el și Patriarh, are un Părinte duhovnicesc de la care primește cuvânt de mântuire și pe care-l ascultă și prin care păstrează neîntreruptă legătura cu Dumnezeu-Tatăl. Aceasta este relația dintre preoția lui Levi și cea după rânduiala lui Melchisedec. Prin urmare ascultarea adevărată este considerată a fi preoția după rânduiala lui Melchisedec, adică aceea care se face ca Hristos și care, mai mult decât cea trupească sau instituționalizată, ne introduce nu doar în Sfânta Sfintelor, ci ne redă și calitatea de fii ai lui Dumnezeu, asemenea lui Iisus Hristos, Fiul Cel Unul-Născut, așezându-ne la dreapta lui Dumnezeu-Tatăl, acolo unde se aduce adevărata jertfă pentru întreaga omenire.

\section{Întâlnirea lui Avraam de la Stejarul Mamvri (Facerea 18, 17-19)}

Deși în Sfânta Scriptură se vorbește despre relația dintre Dumnezeu și Avraam ca despre un legământ, observăm faptul că este vorba de ceva cu mult mai important și mai profund decât o simplă înțelegere. Citind cu atenție Sfânta Scriptură, vom observa cu ușurință că legământul despre care vorbim este de fapt un „exercițiu de ascultare” la care este supus Avraam și pe care îl putem urmări desfășurându-se în mai multe etape care corespund unor trepte în urcușul duhovnicesc către Dumnezeu. Astfel putem să citim parcursul lui Avraam ca fiind unul de înaintare a acestuia în cunoaştere și apropiere de Dumnezeu, în egală măsură.

În ceea ce privește aspectul care ne interesează, adică acela al ascultării, îl vom putea urmări pe Avraam, pe măsură ce crește în ascultare, devenind atât de apropiat lui Dumnezeu încât este ales ca mijlocitor pentru neamul omenesc, ajungând chiar să fie considerat 
foarte apropiat de către Dumnezeu, un intim al Lui (este relevant aici episodul de la stejarul Mamvri, de la Facerea 18, 17-19: Domnul însă a zis: «Tăinui-voi Eu oare de Avraam, sluga Mea, ceea ce voiesc să fac? Din Avraam cu adevărat se va ridica un popor mare și tare și printr-însul se vor binecuvânta toate neamurile pământului, că l-am ales, ca să învețe pe fiii și casa sa după sine să umble în calea Domnului și să facă judecată și dreptate; pentru ca să aducă Domnul asupra lui Avraam toate câte i-a făgăduit»).

La Stejarul Mamvri se poate observa cel mai bine gradul de apropiere de Dumnezeu la care poate ajunge ascultătorul. Acesta nu numai că are o îndrăzneală neobișnuit de mare față de Dumnezeu, dar dă dovadă și de un acut simț al discernământului duhovnicesc. Avraam se comportă aici ca un adevărat mijlocitor între omenire și Dumnezeu (nu trebuie să pierdem din vedere faptul că Dumnezeu îi schimbase deja numele din Avram în Avraam, arătându-l ca Părinte al tuturor neamurilor care Îl urmează pe Dumnezeu). Putem identifica deja aici faptul că Avraam a atins măsura la care a fost chemat omul, împlinindu-se cu el gândul lui Dumnezeu dintru început, acela de a fi mijlocitor între Dumnezeu și Creația Sa și călăuzitor al tuturor către Dumnezeu sau, cu alte cuvinte, chipul Adevăratului Mesia. Parcă se împlinește acum speranța omenirii căzute în venirea unui Mântuitor, speranță căreia i-a dat glas Iov: Căci Dumnezeu nu este un om ca mine, ca să stau cu El de vorbă și ca să mergem împreună la judecată. Între noi nu se află un al treilea care să-și pună mâna peste noi amândoi și care să depărteze varga Sa de deasupra capului meu, aşa încât groaza Lui să nu mă mai tulbure; Atunci aș vorbi și nu m-aș mai teme de El. Dar nu este așa și eu sunt singur cu mine însumi (Iov 9, 32-35).

Este momentul acum când Avraam, arătând că înțelege lucrarea lui Dumnezeu, își arată vrednicia de moștenitor, lucru confirmat de Însuși Dumnezeu Care îl cinstește pe Avraam ca pe un împreună-lucrător la mântuirea lumii. Discernământul lui Avraam se vede nu numai din aceea că nu s-a folosit de îndrăzneala sa pentru sine, ci, mai ales, din aceea că a știut când trebuie să se oprească și să nu mai continue în insistența lui.

Inălțimea la care ajunge acum Avraam reprezintă de fapt intrarea pe un alt drum, acela al povățuirii duhovnicești. Acum ascultătorul se dovedește vrednic de a deveni la rândul său Părinte. De aceea, abia acum este momentul în care Dumnezeu îi dă vestea 
că va avea urmașul făgăduit: Iată, la anul pe vremea asta am să vin iar pe la tine și Sarra, femeia ta, va avea un fiu (Facerea 18, 10).

\section{Jertfa lui Isaac (Facerea 22, 1-18)}

Pentru a deveni Părinte, Avraam trebuie să mai treacă două încercări. Prima este aceea a lepădării totale de sine și de toate cele lumești (încercare cu care Avraam luase deja cunoștință din întâlnirea cu Melchisedec), astfel încât să nu fie nimeni și nimic mai presus decât Dumnezeu, aşa cum va spune mai târziu Hristos: Dacă vine cineva la Mine și nu urăște pe tatăl său și pe mamă și pe femeie și pe copii și pe frați și pe surori, chiar și sufletul său însuși, nu poate să fie ucenicul Meu² (Luca 14, 26). Această încercare îl aduce acum pe Avraam în punctul în care este pus să-l aducă jertfă pe unicul său fiu, pe Isaac, rodul făgăduinței lui Dumnezeu. Este important să menționăm aici faptul că Dumnezeu nu i-ar fi cerut acest lucru lui Avraam dacă acesta nu ar fi avut înălțimea duhovnicească de care am vorbit. Asemănarea jertfei lui Isaac (singurul fiu al lui Avraam) și a jertfei lui Hristos (Unul-Născut al Tatălui) este și ea în măsură să ne arate faptul că ascultătorul este ridicat la cunoașterea Fiului lui Dumnezeu, la starea bărbatului desăvârșit, la măsura vârstei deplinătății lui Hristos (Efeseni 4, 13).

Jertfa lui Isaac ne pune înainte un model al ascultării, în special pentru că este prefigurarea jertfei lui Hristos, Care S-a jertfit din iubire, din ascultare față de Tatăl. Desigur, jertfa lui Isaac nu se ridică la desăvârșirea jertfei Mântuitorului, însă se aseamănă în câteva privințe esențiale: „1. nu este jertfă de animale, ci jertfa omului conștient de valoarea ei negrăită în raport cu cea de animale; 2 . jertfa este cu totul curată, căci nu o face pentru sine, dintr-un fel de interes personal, ci dintr-o desăvârșită dragoste pentru Dumnezeu" ${ }^{\prime 3}$. La aceste aspecte mai adăugăm faptul că cel care aduce jertfa este Avraam care, în cazul acesta, este în același timp și tată și fiu, simbolizând astfel ascultarea lui Hristos Care, în același timp, Îl arată întru Sine și pe Tatăl Care L-a trimis, dar Se înfățișează pe Sine și ca Fiu, fiind prin aceasta și jertfă și jertfitor în același timp. Avraam

${ }^{2}$ Aceste cuvinte sunt cele pe care un monah le aude permanent în viața de mănăstire, începând din momentul în care este tuns în monahism.

${ }^{3}$ Pr. Dumitru Stăniloae, Chipul nemuritor al lui Dumnezeu, în col. „Opere complete", vol. 5, Editura Basilica, București, 2013, p. 725. 
dă astfel dovadă de o iubire dublă în jertfa pe care o aduce în persoana fiului său Isaac: de iubire paternală și filială.

Ajuns în acest punct, Avraam trebuie să treacă cea de-a doua încercare pentru a se putea numi Părinte și anume aceea de a transmite esența învățăturii sale (moștenirea sa) urmașilor săi, reprezentați aici de Isaac. Un Părinte trebuie mai întâi să fie în stare să intre în gândul lui Dumnezeu spre a-1 desluși, pentru ca mai apoi să-1 transmită ca moștenire fiilor săi duhovnicești. Această învățătură este cea care dă mărturie de prezența și lucrarea lui Dumnezeu în viața omului, fiind expresia cea mai limpede și vie a relației dintre om și Dumnezeu. Acesta este lucrul care-i dă Părintelui certitudinea că fiii săi nu vor rătăci de la calea care duce la îndumnezeire.

Încercarea despre care vorbim este aceea prin care Dumnezeu îi cere lui Avraam un lucru de neconceput: să-și aducă propriul său fiu ca ardere de tot! Pentru Avraam acest lucru era cu atât mai greu de primit, cu cât Isaac, fiul său, era în același timp atât rodul, cât și garanția împlinirii făgăduinței lui Dumnezeu. După ce lui Avraam i s-a cerut să-și părăsească locul în care s-a născut și neamul său, după ce a fost nevoit să-1 părăsească și pe Ismael, întâiul său rod, iată că acum, după o așteptare atât de îndelungată a împlinirii făgăduinței lui Dumnezeu că va avea numeroși urmași, i se cere să renunțe și la această dovadă a împlinirii făgăduinței. Este ca și cum i se cere lui Avraam să renunțe la tot ce avea sau ar putea să aibă: după ce a renunțat la trecut, să renunțe și la viitor! Cu toate acestea, ceea ce rămâne și la care nu trebuie să renunțe, ci dimpotrivă, este prezentul, acel veșnic „,Acum”, care este timpul lui Dumnezeu, clipa veșnică a sărbătoririi evenimentului întâlnirii dintre om și Dumnezeu. Îl vedem pe Avraam că nu are nici cea mai mică ezitare atunci când primește porunca de la Dumnezeu, deși i se dăduse răgaz încă o zi. Iată lucrarea unui adevărat ascultător: îndată ce aude porunca Părintelui, se silește să o așeze în inima sa de la primul cuvânt, fără a se mai îngriji de nimic, nici de rostul acestei porunci, nici de sfârșitul ei și nici măcar de felul în care ar trebui s-o împlinească mai bine. Odată ce ascultătorul primește primul cuvânt și se silește să-l așeze imediat în inima sa, nici un gând vrăjmaș nu-l mai poate clinti din drumul său! (Iată o învățătură atât de necesară celui care vrea să pășească pe calea aceasta a ascultării!) 
Adevărata așezare a lui Avraam se va lămuri însă abia în momentul în care își vede fiul, pe Isaac, cuprins de îngrijorare (care este sentimentul cel mai nociv pentru un ascultător!) din pricina lipsei „oii pentru jertfă” (Facerea 22, 7). Este de înțeles îngrijorarea lui Isaac, deoarece era pusă în pericol însăși lucrarea lor duhovnicească, anume închinarea lor înaintea lui Dumnezeu. Era ca și cum astăzi, am vrea să săvârșim Sfânta Liturghie și ne-am vedea în imposibilitatea de a face acest lucru din cauză că ne lipsesc cele necesare. Trebuie să observăm înălțimea duhovnicească a lui Avraam care, deși era pus într-o situație deosebit de grea și de tensionată (care ar fi putut tulbura pe oricine), nu-și pierduse nici un moment nici așezarea lăuntrică, nici afecțiunea pentru Isaac. Este foarte relevantă aici atitudinea lui Avraam față de fiul său, care arată faptul că ascultarea lui era foarte bine înrădăcinată pe încrederea deplină în purtarea de grijă a lui Dumnezeu. Isaac a exclamat simplu, spunând doar atât: „Tată!”, iar Avraam îi răspunde imediat, cu duioșie: „Ce este, fiul meu?". Isaac era îngrijorat de faptul că neavând oaia pentru jertfă, tatăl său și cu sine erau în imposibilitatea de a-și duce la bun sfârșit datoria față de Dumnezeu. Prin răspunsul pe care i l-a dat, Avraam îi încredințează lui Isaac esența învățăturii și a moștenirii sale duhovnicești: Fiul meu, va îngriji Dumnezeu de oaia jertfei Sale! (cf. Facerea 22, 7-8). Avraam îi transmite astfel fiului său adevăratul conținut al tainei ascultării, anume încredințarea în purtarea de grijă a lui Dumnezeu, singurul lucru în care un ascultător își află deplina liniște și așezare. Mărturie pentru acest lucru stă felul în care Avraam a însemnat acel loc în care S-a făcut arătat numele lui Dumnezeu și în care a strălucit Slava Sa: Avraam a numit locul acela «Iahve-ire», adică, Dumnezeu poartă de grijă și de aceea se zice astăzi: «În munte Domnul Se arată» (Facerea 22, 14). Această învățătură este una deosebit de importantă pentru ascultare, deoarece a te lăsa cu totul în mâna lui Dumnezeu (dar mai ales a rămâne liniștit acolo) este lucrarea ascultătorului desăvârșit pentru că, aşa după cum spun Părinții, Însuși Fiul Își află liniștea în purtarea de grijă a Tatălui.

\section{Lupta lui Iacov cu Îngerul (Facerea 32, 24-29)}

Acest moment este considerat în tradiția monahală ca fiind cel mai reprezentativ pentru ceea ce este un monah, referindu-se în special la momentul intrării lui în viața monahală. Pe scurt, Cartea 
Facerii prezintă un moment de cotitură în viața lui Iacov. După ce slujise 20 de ani în casa socrului său, Laban, Iacov a vrut să-l părăsească pe acesta, din cauză că fusese înșelat de „zeci de ori” de el și prin urmare dorea cu tot dinadinsul să rupă orice legătură cu el. Aici, Laban simbolizează lumea aceasta care își aruncă mrejele ei asupra celor care doresc să se îndestuleze cu bogățiile și plăcerile ei, reușind totdeauna să găsească legăturile necesare pentru a-i robi pe cei care cad sub amăgirea ei. Acest lucru se întâmplă și cu Iacov care, pentru a dobândi ceea ce-și dorise, a fost silit (prin înșelăciune) să muncească 14 ani pentru cele două soții - Lia și Rahila - și 6 ani pentru vite (pentru a-și face propria avere).

Însă, așa cum se întâmplă întotdeauna în această lume, cu cât zăbovești mai mult în ea, cu atât te lași mai ușor amăgit de toate plăcerile și averile ei, astfel încât ajungi ca în final să nu te mai poți dezlipi de ele. Astfel s-a întâmplat și cu Iacov care, dându-și seama că Laban nu-1 mai lăsa să plece, a hotărât să fugă pe ascuns. A hotărât cu alte cuvinte să-l înșele pe socrul său. Puterea și curajul de a face acest pas i-au venit de la Dumnezeu, Care l-a chemat să se întoarcă în pământul părinților săi, spunându-i: Intoarce-te în țara părinților tăi, în patria ta și Eu voi fi cu tine (Facerea 31, 3).

Se vede aici că lupta de a părăsi lumea este întotdeauna inegală, depășind puterea omenească. Cu toate acestea, în momentul în care Dumnezeu pune chemarea Sa în inima omului, acesta capătă puterea nu numai de a părăsi lumea, ci și de a-și schimba felul de viețuire. În această privință, este relevantă pentru persoana lui Iacov însemnătatea numelui său (Iacov înseamnă ,,cel care înlocuiește”), deoarece îl arată pe acesta ca fiind cel care a reușit să schimbe o obișnuință cu alta. Faptul că a plecat fără să-l anunțe pe socrul său ilustrează cum nu se poate mai bine felul în care poate cineva să facă acest pas, pentru a părăsi lumea. Astfel, Iacov a dat imediat curs chemării lui Dumnezeu, ceea ce subliniază importanța ascultării primului cuvânt și a împlinirii lui imediate. Cu cât întârzie cineva să urmeze chemarea Domnului, cu atât inima lui se răcește, pierzând puterea de a urma calea desăvârșirii și limpezimea vederii acesteia. Faptul că a plecat pe ascuns arată că nu te poți dezlipi de această lume și de obiceiurile ei decât dintr-odată. Nu poți scăpa decât fugind. Această fugă ne învață alte două lucruri. Întâi de toate suntem învățați să nu ne luptăm fățiș cu diavolul căci vom pierde lupta căzând în înșelarea lui. Însuși Domnul nostru Iisus ne-a 
arătat sensul în care putem depăși ispita, prin cuvintele: Mergi înapoia Mea satano! (Matei 16, 22). De asemenea, suntem învățați să ne luptăm din răsputeri cu ispita de a ne uita înapoi, deoarece acela care fuge nu se mai uită în urmă.

Revenind la Iacov, îl vedem pe acesta trecând noaptea râul Iaboc (care înseamnă golire, deșertare) și ajungând într-un loc unde, spune referatul biblic, rămânând singur, S-a luptat Cineva cu dânsul, până la revărsatul zorilor (Facerea 32, 24). Acest moment este tâlcuit ca fiind o teofanie a Vechiului Testament, adică un moment în care Dumnezeu nu doar Se arată omului, ci Se și întâlnește cu acesta. Întâlnirea aceasta este un caz singular, prin aceea că se concretizează printr-o luptă, dar mai ales prin faptul că omul a ieșit biruitor. Dumnezeu, spunându-i lui Iacov că a biruit, îi schimbă și numele în Israel.

Sunt câteva aspecte asupra cărora vom zăbovi. Observăm mai întâi faptul că atât trecerea râului Iaboc, cât și confruntarea care a urmat, se fac noaptea. La această primă observație mai adăugăm și faptul că Dumnezeu S-a apropiat de Iacov doar în momentul în care acesta a rămas singur. Găsim aici ilustrat modul în care își săvârșesc monahii nevoința rugăciunii: În primul rând ei fac acest lucru noaptea, atunci când focul amăgirilor lumești se potolește (cf. Psalmi 41, 11: Ziua a poruncit Domnul milei Sale, iar noaptea, cântare Lui de la mine). În al doilea rând monahul, pentru a se putea așeza înaintea Domnului și a fi văzut de Acesta, trebuie să treacă râul Iaboc, adică să se golească de grijile lumești și să se deșerte pe sine prin smerenie. Apoi el trebuie să fie singur, să stea înaintea lui Dumnezeu fără fățărnicie și cât mai autentic, mai personal, astfel încât să considere că numai el și Dumnezeu sunt pe pământ. În ultimul rând rugăciunea este tensionată, de aceea se și cheamă „,nevoință", pentru că monahul se luptă în primul rând cu sine însuși, după cum spune Sfântul Ioan Scărarul: „,călugăr este cel ce supune firea sa unei sile neîncetate și simțurile sale unei paze neîntrerupte" ${ }^{\prime 4}$. Cu toate acestea, adevărata luptă pe care o duce este cu Dumnezeu și numai după ce biruie, Iacov primește un nou nume. Aici Părinții tâlcuiesc această schimbare a numelui prin trecerea pragului de

${ }^{4}$ Sfântul Ioan Scărarul, Scara dumnezeiescului urcuş, cuv. 9, în col. „Filocalia”, vol. IX, traducere, introducere și note de pr. D. Stăniloae, EIBMBOR, București, 2013, p. 67. 
la trupesc (Iacov) la duhovnicesc (Israel). Abia atunci își începe, de fapt, drumul întoarcerii în casa părintească; abia atunci el a dovedit că a părăsit cu adevărat și definitiv lumea, primind un alt nume, lucru echivalent cu calitatea de „cetățean al Raiului”. Asemănarea cu tunderea în monahism este evidentă.

Lucrul cel mai important l-am lăsat însă la sfârșit. Este vorba despre lupta cu Dumnezeu și, mai ales, în ce a constat aceasta. Tradiția monahală arată că lupta aceasta a constat în aceea că monahul refuză să primească darul pe care ceilalți oameni îl socotesc ca fiind cel mai prețios, adică liberul arbitru sau libertatea de a alege.

Aici se vede poate cel mai important aspect al ascultării, cel pe care Sfântul Ioan Scărarul l-a definit prin cuvintele: , ascultarea este lepădarea judecății proprii dintr-o bogăție a judecății ${ }^{5 \prime \prime}$.

Monahul face, prin intrarea în mănăstire, ultima alegere, renunțând la a mai face orice altă alegere ulterioară. El renunță la rațiunea sa proprie pentru că urmărește să dobândească o rațiune superioară. Renunță la ceea ce-l definește ca om, pentru a se putea ridica la înălțimea îngerilor, iar când face acest lucru, Dumnezeu Se arată biruit, pentru că asta înseamnă că omul intră, de bună voie, în voia lui Dumnezeu și face acest lucru silindu-se pe sine. Hristos Însuși a spus că Împărăția Cerurilor se ia prin străduință și cei ce se silesc pun mâna pe ea (Matei 11, 12). De aceea, nu puțini au fost comentatorii care L-au identificat pe Hristos în Persoana („Cineva” - v. 24) Care S-a luptat cu Iacov și a fost biruit de acesta din urmă, lucru susținut și prin cuvântul Mântuitorului, Care a arătat că Se lasă pe Sine la urmă pentru a-l face biruitor pe om, zicând: Adevărat, adevărat zic vouă: cel ce crede in Mine va face și el lucrările pe care le fac Eu și mai mari decât acestea va face (Ioan 14, 12). Acest cuvânt de pe urmă arată și faptul că Dumnezeu îl face pe ascultător părtaș încă din această viață roadelor contemplării viețuirii dumnezeiești, introducându-l în Tainele Sale. De aceea, Dumnezeu, deși nu-i spune lui Iacov Numele Său, îl face părtaș totuși unei alte minuni, aceea

${ }^{5}$ Tâlcuirea pr. Stăniloae: „,Lepădarea judecății (a discernământului, a alegerii proprii) stă în a asculta pe cele ce par rele ca fiind bune, precum Avraam împlinind porunca de a junghia pe fiul său, și-a îmbogățit fără să judece ascultarea pe care o avea de la început. Ascultarea de Dumnezeu vine din bogăția înțelegerii adevărate a ceea ce trebuie făcut pentru propria realizare și îmbogățește această înțelegere prin experiența continuă pe care o face cel ce ascultă despre propășirea sa în eliberarea de mândrie" (n.s. 105, pp. 103-104).

${ }^{6}$ Sfântul Ioan Scărarul, Scara..., cap. IV, cuv. 4, p. 103. 
de a se împărtăși de binecuvântarea care se revarsă din Acesta: Numele Meu este minunat. Și zicându-i aceasta, L-a binecuvântat acolo (cf. Facerea 32, 29).

Această renunțare la voia proprie, sau refuzul monahului de a primi darul de care toți cei din lume se bucură, este lupta în care binevoiește Dumnezeu. Totuși, această luptă nu este ușoară, nu se face fără o anumită jertfă, motiv pentru care Dumnezeu, deși S-a declarat învins, îl rănește pe Iacov în coapsă. Acest fapt are pentru ascultare dublă însemnătate.

Cel mai important aspect este acela că ascultarea presupune o nevoință continuă, la fel cum și durerea provocată de o rană în coapsă nu poate fi trecută cu vederea, cu atât mai mult cu cât îti îngreuiază și mersul. Aceasta este echivalent cu a pune mereu început bun în ascultare sau, la fel cum atunci când ai o rană în coapsă ai nevoie de bărbăție pentru a-ți învinge durerea și a-ți continua drumul, tot așa este nevoie ca în orice lucru pe care-l săvârșești să te birui pe tine. Un al doilea aspect ce trebuie subliniat este acela că rana în coapsă face trimitere la moștenire. Este foarte des întâlnită în Vechiul Testament expresia provenit din coapsa lui... ${ }^{7}$. Fiind vorba de o rană provocată de Dumnezeu, deducem de aici că este vorba de moștenirea duhovnicească, de „rana” care nu se vindecă, ci care se transmite fiilor duhovnicești. Putem înțelege de aici și pocăința, dar, mai ales, putem să vedem aici „întristarea după Dumnezeu" despre care vorbește Sfântul Apostol Pavel (cf. 2 Corinteni 7, 10: Căci întristarea cea după Dumnezeu aduce pocăință spre mântuire, fără părere de rău; iar întristarea lumii aduce moarte). De asemenea, coapsa era în Vechiul Testament un semn al jurământului sau al făgăduinței, deoarece atunci când i se cerea cuiva să facă un jurământ sau făgăduință, i se cerea respectivului să facă acest lucru punând mâna pe coapsa aceluia în fața căruia (sau față de care) se depunea jurământul (a se vedea: Facerea 24, 9 și Facerea 47, 29).

\section{Rugăciunea din Grădina Ghetsimani (Matei 26, 36-45; Marcu 14, 32-41)}

„Niciodată nu a reprezentat pe vreo scenă o persoană în chip atât de real toată omenirea, ca lisus în Ghetsimani. Pe scena aceea universală, pe care fiecare din noi a fost prezent prin voia lui Iisus

\footnotetext{
${ }^{7}$ Vezi: Facerea 15, 4; 35, 11; 46, 26; 49, 10; 50, 23; Deuteronomul 28, 57; Judecători 8, 30; 2 Regi 7, 12; 16, 11; 3 Regi 8, 19; 2 Paralipomena 6, 9; Iov 19, 17.
} 
Hristos, s-a decis în bine soarta tuturor celor ce vor să tragă consecințe pozitive pentru ei, toți au dobândit supremația asupra păcatului și a morții"8.

Înainte de Pătimirea Sa, Hristos Și-a arătat dorința Sa cea mai fierbinte, care cuprinde și scopul pentru care a venit în lume, și anume, $c a$ toți să fie una, după cum Tu, Părinte, întru Mine și Eu întru Tine, așa și aceștia în Noi să fie una, ca lumea să creadă că Tu M-ai trimis (Ioan 17, 21). Aceasta cuprinde în sine esența voii lui Dumnezeu-Tatăl de unde rezultă faptul că și ascultarea Fiului are ca și conținut unirea oamenilor între ei și cu Dumnezeu.

În episodul din Grădina Ghetsimani se poate observa cel mai bine această voință a Tatălui, pe care Fiul Și-a asumat-o dureros, dar deplin. Sfâșierea lăuntrică a lui Hristos a atins atunci maximul de intensitate, deoarece El, Care a luat asupra Sa păcatul întregii omeniri, a trebuit să ia odată cu acesta și responsabilitatea lui. Atunci, stând înaintea Tatălui pentru a mijloci iertarea oamenilor pentru păcatul depărtării de Dumnezeu și al înrobirii de bună voie față de păcat, Fiul a fost nevoit să îndure în mod desăvârșit rușinea pentru toate păcatele omenirii, fiindcă El a luat asupra Sa responsabilitatea pentru ele. De aceea, și privirea Tatălui, plină de reproș față de omenire pentru depărtarea ei păcătoasă, era acum îndreptată spre Fiul Său. Atunci a început să simtă Hristos „părăsirea" de către Tatăl, care însemna de fapt părăsirea (ca și depărtarea) pe care le trăia întreaga omenire. Dar, această privire plină de reproș a Tatălui era îndreptată asupra păcatului omenirii și nu asupra Persoanei Fiului. Este, după cum spune Părintele Stăniloae, „o părăsire și o iubire în același timp pentru că actul lui Iisus de asumare a păcatului străin este un act de supremă valoare etică și împlinirea lui este în același timp o împlinire a voii Tatălui, o ascultare a Lui. Tatăl părăsește pe Iisus, dar Îl părăsește îndurerat și durerea aceasta este expresia iubirii Lui. El îl lasă să sufere pentru păcatul care nu este al Lui, dar suferința aceasta Îl doare și pe El. Cu dreptate spune Bulgakov 9 că ,,trista noapte a Ghetsimanilor reprezintă tristețea întregii Sfinte Treimi". Omenirea Sa, părăsită de Dumnezeu și

${ }^{8}$ Pr. Dumitru Stăniloae, Iisus Hristos sau restaurarea omului, în col. „Opere complete", vol. 4, Editura Basilica, București, 2013, p. 231.

${ }^{9}$ Sergius Bulgakov, The Lamb of God, trad. Boris Jakim, Eerdmans, Grand Rapids, 2008, p. 370. 
lăsată să sufere pentru păcat, s-a simțit sfârșită în noaptea Ghetsimanilor și în sudori de sânge a strigat către Tatăl: «De este cu putință, treacă acest pahar de la Mine! ${ }^{10}$

Cu cât iubești mai mult pe cineva, cu atât mai insuportabilă îți este suferința acestuia, de aceea Hristos în Grădina Ghetsimani a simțit (ca om mai întâi, dar om care simțea iubirea Fiului față de Tatăl) că puterea Sa omenească nu era de ajuns pentru a merge mai departe, așa încât a strigat: Părintele Meu, de este cu putință, treacă de la Mine paharul acesta! Acest strigăt arată nu doar o neputință a firii omenești, ci și o chenoză de negrăit a Celui fără de păcat, Care a trebuit să ia asupra Sa păcatul. Celui păcătos, păcatul nu i se pare o povară de nesuportat, celui drept însă această murdărie i se pare cu totul de neacceptat. Prin urmare, Hristos a luat asupra Sa păcatul lumii ca pe ceva cu totul străin și cu totul respingător ${ }^{11}$, iar prin faptul că asumându-Și acest păcat a trebuit să suporte și depărtarea de Dumnezeu-Tatăl, această durere I-a devenit insuportabilă, astfel încât chinul Lui și strigătul care a izbucnit din el au fost cu totul îndreptățite. Păcatul trebuia asumat până la capăt și împreună cu toate urmările lui. Dacă nu înțelegem așa, suntem în pericolul căderii în dochetism, dar ar însemna totodată că nu credem că Hristos a răscumpărat tot păcatul lumii. Prin urmare, Mântuitorul a băut paharul până la capăt și nediluat, biruind astfel păcatul întregii omeniri în Persoana Sa. Acest lucru a fost rezultatul supunerii voii Sale omenești voii lui Dumnezeu-Tatăl și astfel, Noul Adam, spunând aceste cuvinte: Însă nu precum voiesc Eu, ci precum Tu voiești (cf. Matei 26, 39; Marcu 14, 36), l-a ridicat pe întâiul Adam din neascultarea sa.

În ascultarea Sa de voia Tatălui, Hristos a arătat puterea iubirii Sale care a biruit și păcatul și care, recapitulând întreg neamul omenesc, a adus biruința Întregului Adam asupra păcatului și a morții. „Dar iubirea are multe forme de a se manifesta, după țintele pe care le urmărește. Uneori se manifestă în smerenie și suferință. Dar și prin forma aceasta iubirea își arată puterea. Iubirea în smerenie și suferință a Dumnezeu-Omului a spălat păcatul omenesc, a desfundat drumul de la Dumnezeu la om și viceversa" ${ }^{\prime 2}$.

\footnotetext{
${ }^{10}$ Pr. Dumitru Stăniloae, Iisus Hristos sau restaurarea omului..., pp. 363-364.

${ }^{11}$ Sergius Bulgakov, The Lamb of God..., p. 360.

${ }^{12}$ Pr. Dumitru Stăniloae, Iisus Hristos sau restaurarea omului..., p. 366.
} 
Când ești în acord deplin cu voia Tatălui vrei, la fel ca și El, ca toți oamenii să se mântuiască (1 Timotei 2,4) și atunci simți dureros depărtarea lor de Dumnezeu. Conform principiului ipostatic sădit în om de către Dumnezeu, fiecare om poate participa la firea sau natura celuilalt, putând să recapituleze în sine, în persoana sau ipostasul său, toată firea omenirii (desigur, nu în mod deplin ca Hristos, ci împărțit, nedesăvârșit). Această participare la firea celorlalți nu înseamnă că se anulează în vreun fel personalitatea fiecărui om în parte (căci vorbim despre fire, nu despre persoană), ci că avem puterea de a activa în celălalt - într-un sens sau altul, în bine sau rău - puterile sufletești ale aceluia. Vorbind despre ascultare, putem afirma faptul că un adevărat ascultător poate trezi în cel cu care intră într-o relație mai strânsă capacitatea de a se supune voii lui Dumnezeu, îmbinând-o cu dorul după unirea cu El. Fiind calea către smerenie, desigur că prin această participare, ascultarea se aplică cu atât mai mult la transmiterea (înțeleasă ca molipsire) și trezirea puterii esențiale și definitorii a firii omenești, care este smerenia, deoarece „umanul a fost creat ca un mod smerit de trăire a divinului" ${ }^{\prime 3}$. Astfel putem înțelege spre lucrare cuvântul Avvei Paisie: „... Du-te, lipește-te de omul care se teme de Dumnezeu și, apropiindu-te, te vei învăța și tu a te teme de Dumnezeu" ${ }^{\prime 14}$. Prin urmare, rămânând în ascultare de voia lui Dumnezeu, putem să fim în ascultare și de frații noștri și împreună să-l refacem pe Adam cel dintru început. Sfântul Sofronie Saharov spunea că omul, doar printr-o rugăciune asemenea celei din Grădina Ghetsimani, în care Hristos S-a rugat pentru întreaga lume ca pentru Sine Însuşi, poate cuprinde în experiența sa personală ,,adevărul ființial al «celei de-a doua porunci» (Matei 22, 39; Marcu 12, 31): întregul Adam devine un singur Om-Omenire"15.

Părinții, în numeroase rânduri și în multe feluri, ne învață faptul că firea noastră nu se poate lărgi decât prin smerenie. Doar omul smerit își poate lărgi firea, astfel încât în el să poată încăpea atât lumea întreagă, cât și darurile Duhului Sfânt. Dar această smerenie nu se poate învăța decât de la Hristos, prin unire cu El, așa

${ }^{13}$ Pr. Dumitru Stăniloae, Chipul nemuritor..., p. 561.

${ }^{14}$ Patericul egiptean, "Pentru Avva Pimen”, Editura Episcopiei Ortodoxe a Alba Iuliei, Alba Iulia, 1993, p. 174.

${ }^{15}$ Arhim. Sofronie Saharov, Vom vedea pe Dumnezeu precum este, Editura Sophia, București, 2004, p. 286. 
după cum El a spus: Învățați-vă de la Mine, că sunt blând și smerit cu inima! (Matei 11, 29). Iar calea prin care Hristos S-a smerit pe Sine, este cea pe care ne-a arătat-o Sfântul Pavel: S-a smerit pe Sine, ascultător făcându-Se până la moarte, și încă moarte pe cruce (Filipeni 2, 8). Prin urmare, dacă este cineva care nu-l poate purta pe fratele său curat în inima sa, care încă mai are ceva împotriva cuiva, acela nu este în ascultare! Și iarăși, doar dacă te silești să faci ascultare poți să-i porți în inima ta pe toți, așa cum sunt ei. Tradiția ascetică ne învață că pentru a ne asemăna cu Hristos, trebuie să ajungem la măsura în care să nu putem purta pe nimeni murdar în inima noastră. Fiul lui Dumnezeu ne-a arătat prin smerenia Sa calea către îndumnezeirea tuturor oamenilor adunați într-un trup, în trupul Lui Tainic.

Din acest model biblic al ascultării din Rugăciunea din Grădina Ghetsimani se poate contura o caracteristică foarte importantă a ascultării, care a fost insuficient sau aproape deloc subliniată de literatura teologică a zilelor noastre. Este vorba de faptul că ascultarea are ca scop principal mântuirea tuturor oamenilor și ea lucrează în special iubirea dintre oameni și unirea dintre ei ca frați. Nu trebuie înțeleasă ascultarea ca fiind o nevoință sau lucrare personală, a unui singur om, având ca scop desăvârșirea acestuia ca persoană. Ascultarea nu este un act pe care îl facem în izolare, iar legătura dintre ascultare și iubirea față de toți oamenii, de întreg Adamul, este indisolubilă. Ascultarea adevărată, autentică - care ne face asemenea lui Hristos - este aceea care își asumă nu doar păcatele proprii, ci și pe ale altora, dar care (și) în suferința ei își arată adevărata putere care-i vine din iubire, pentru că ea ne poate mântui nu numai pe noi, ci și întreaga omenire.

\section{Pescuirea minunată - A treia arătare a lui Hristos de după Înviere, de la Marea Tiberiadei (Ioan 21, 2-13)}

Acest moment expus de Sfântul Evanghelist Ioan descrie a treia arătare a lui Iisus Hristos, de după Înviere, înaintea ucenicilor Săi. Pe scurt, două sunt detaliile care ne atrag atenția și care ne dezvăluie alte două aspecte sau caracteristici ale ascultării.

Mai întâi de toate observăm faptul că cel dintâi Apostol care L-a recunoscut pe Mântuitorul, spunând că Domnul este!, a fost ucenicul cel mai iubit al lui Hristos, cel care era și cel mai ascultător, anume Ioan. Tot el este acela care alergând, a ajuns înaintea lui 
Petru la mormânt. Atunci, Ioan a alergat înaintea lui Petru (Ioan 20, 3) și „,ascultarea s-a pus aici înaintea pocăinței. Cel dintâi, ajungând înainte, închipuie ascultarea, celălalt închipuie pocăința" ${ }^{16}$. Este de reținut aici faptul că Ioan, și aici la fel ca și atunci la mormânt, nu s-a grăbit să alerge către Mântuitorul așa cum a făcut Petru, ci dimpotrivă, acum ca și atunci, s-a mulțumit să rămână pe loc. De aici observăm că un adevărat ascultător, prin relația specială, foarte strânsă pe care o are cu Părintele său, fiindu-i acestuia foarte familiar, este primul care-și recunoaște Părintele fără a avea vreun dubiu. De asemenea, familiaritatea pe care o are cu Părintele său, îl hrănește în mod nevăzut, motiv pentru care el nu simte nevoia să se grăbească spre Părinte și, în felul acesta, vedem cum pentru ascultător, depărtarea de Părintele său nu devine prilej de ieșire din așezarea sa lăuntrică sau, mai bine zis, depărtarea i se face ascultătorului apropiere.

Mai putem înțelege din acest moment și o altă calitate a ascultării, anume aceea că măreția ei o ridică deasupra oricărei minuni. Petru avea experiența ascultării de Învățătorul său, dintr-o situație similară acesteia de acum, când, la cuvântul lui Hristos de a arunca mreaja mai la adânc, a răspuns: Învăţătorule, toată noaptea ne-am trudit și nimic nu am prins, dar, după cuvântul Tău, voi arunca mrejele (Luca 5, 5) și a văzut cu ochii săi minunea lucrată pentru ascultarea pe care a arătat-o față de cuvântul Domnului. Acum, fără să mai întrebe nimic, a ascultat fără șovăială de cuvântul Mântuitorului Hristos și a fost martor la aceeași minune ca și odinioară. Important pentru noi în ceea ce privește ascultarea este să observăm ce s-a întâmplat atunci când Apostolii au ajuns pe țărm. Atunci L-au văzut pe Mântuitorul Care, deși mai înainte le ceruse ucenicilor ceva de mâncare, acum avea înaintea Lui pește proaspăt fript. Este de la sine înțeles că acest pește fusese prins de către Hristos în mod minunat, fiind cu alte cuvinte un rod al minunii săvârșite direct de către Dumnezeu. Cu toate acestea Hristos le spune ucenicilor Săi aceste cuvinte: Aduceți din peștele pe care l-ați prins acum! (Ioan 21, 10). Putem înțelege de aici faptul că Hristos a pus ascultarea mai presus decât minunile. Citim în Pateric o întâmplare asemănătoare, în care unui frate i-a poruncit Părintele său ca să ude un băț înfipt în pământ. Ascultând fratele de cuvântul Părintelui

\footnotetext{
${ }^{16}$ Sfântul Ioan Scărarul, Scara..., cuv. 5, p. 165.
} 
și udând acel băț în fiecare zi, după trei ani a rodit bățul. Atunci Părintele s-a minunat foarte tare și chemându-i pe toți frații, le-a pus înainte fructele zicându-le: „Luați și mâncați rodul ascultării”"17.

Din cele spuse mai sus rezultă că ascultarea se ridică deasupra oricărei minuni pentru că ea lucrează asemănarea și unirea cu Hristos, sau îndumnezeirea, care depășește orice altă minune săvârșită pe pământ.

\section{Buna Vestire (Luca 1, 26-38)}

Dacă ar fi să căutăm un cuvânt care să poată cuprinde în sine toată ascultarea omenirii, atunci cu siguranță acel cuvânt este „Fie" pe care l-a rostit Maica Domnului și prin care întreaga lucrare de mântuire a lumii - sau ascultarea Fiului de Tatăl - și-au găsit intrarea pe făgașul aflat în gândul lui Dumnezeu. De aceea am găsit de cuviință să încheiem, sau mai bine zis să încununăm acest studiu cu ascultarea Maicii Domnului.

Odinioară, o Fecioară i-a răspuns Îngerului trimis la ea de Dumnezeu aceste cuvinte: Iată roaba Domnului. Fie mie după cuvântul tău! (Luca 1, 38) și atunci s-a întâmplat cu ea toate cele pe care Gavriil Arhanghelul i le spusese: Duhul Sfânt Se va pogorî peste tine și puterea Celui Preaînalt te va umbri; pentru aceea și Sfântul care Se va naște din tine, Fiul lui Dumnezeu se va chema (Luca 1, 35). În urma acestui răspuns Dumnezeu a putut să-Și înceapă lucrarea Sa de mântuire a lumii; prin acest răspuns omul s-a putut întoarce în inima lui Dumnezeu, a putut reintra în gândul lui Dumnezeu. Ascultarea realizează unirea dintre Părinte și ucenic, pentru că face lucrarea iubirii. În fapt, ascultarea presupune o sinergie având ca și conținut iubirea. Este porunca din iubire a Părintelui care se întâlnește cu împlinirea poruncii de către ucenic ca răspuns iubitor. De fapt, amândoi se află în ascultare și aceasta este adevărata fire a omului.

Părintele este după chipul Tatălui, însă în același timp este și după chipul Fiului. Atunci când „poruncește”, când transmite primul cuvânt, arată în el pe Tatăl, căci aceasta este „ascultarea” lui. Când îl îndrumă pe ucenic prin învățături, dar mai ales prin

\footnotetext{
${ }^{17}$ Patericul Mare, „Despre ascultare”, traducere, introducere și note de pr. prof. Constantin Coman, Editura Bizantină, București, 2016, p. 685.
} 
exemplul personal, atunci este după chipul Fiului, căci îl îndrumă pe ucenic către Tatăl (cf. Ioan 16, 23-26; 1 Corinteni 15, 28). Ascultarea restaurează omul, reașezându-l în firea lui. La fel s-a întâmplat și la Buna Vestire: o împreună-ascultare! Ascultarea Fiului s-a unit cu ascultarea Maicii. Împreună-lucrare, ca o împreună-naștere. Luând trup din Maica Domnului, Hristos S-a născut pe Sine, în sensul că Și-a format singur trupul, căci era nevoie ca în această Întrupare să existe și componenta „facerii" ca în cazul lui Adam. Dar, prin intervenția Sfintei Treimi (Duhul Sfânt Se va pogorî peste tine și puterea Celui Preaînalt te va umbri - Luca 1, 35) și Maica Domnului a fost renăscută. În aceasta găsim și explicația evoluției răspunsului pe care 1-a dat ea la invitația Arhanghelului, de la rezistență (aproape de refuz) până la acceptare. Ea a simțit nu doar prezența Fiului lui Dumnezeu în ea, ci și lucrarea Lui, de aceea acceptarea ei a însemnat de fapt intrarea ei în împreuna-lucrare cu Fiul lui Dumnezeu, care însemna de fapt împreună-ascultare față de voia Tatălui. Astfel, răspunsul iubitor al Fiului la trimiterea de către Tatăl a lucrat și în Maica Domnului ascultarea, refăcându-i acesteia rodnicia firii umane sau capacitatea de a da răspunsul cuviincios la chemarea lui Dumnezeu:

„Născându-Se ca om din Fecioară, Fiul lui Dumnezeu a dat această tărie nu numai chipului Său uman, ci și Fecioarei în mod deosebit, prin Duhul Său cel Sfânt, refăcând în ea rodnicia firii umane... Prin aceasta, ea este ca un templu viu și însuflețit al Cuvântului și Fiului, Care își trăiește și ca om toată iubirea de Fiu față de Tatăl, dar și iubirea Tatălui față de El ca om și, prin El, față de toți oamenii și, în primul rând, față de Maica Lui. Ea este negrăit de unită cu El, participând într-un fel, prin simțirea spiritualizată, la Întruparea Lui mântuitoare, iar după naștere, la toate actele Lui mântuitoare" ${ }^{\prime 18}$.

Prin urmare, acel „Fie!” al Maicii Domnului este rezultatul împreună-lucrării dintre Fiul lui Dumnezeu și Maica Domnului, oglindindu-se în el ascultarea conjugată a Fiului și a Maicii față de Tatăl. Maica Domnului, prin ascultarea ei desăvârșită, a putut da naștere Fiului lui Dumnezeu Cel Singur adevărat Ascultător, rămânând într-o veșnică și deplină legătură cu El, devenind prin aceasta ea și Maica noastră, a tuturor celor botezați în Numele Lui.

\footnotetext{
${ }^{18}$ Pr. Dumitru Stăniloae, Chipul nemuritor..., pp. 599-600.
} 
Participând în mod direct la toată lucrarea de mântuire a lui Hristos asupra noastră, Maica Domnului devine parte și la ascultarea de care ne împărtășim prin unirea cu Hristos. De fapt, prin ea (și doar prin ea) ajung la noi - cei care alcătuim trupul lui Hristos - toate energiile dumnezeiești care iradiază din Capul Bisericii - Hristos:

„Mama lui lisus poartă în chip nemijlocit Capul cel mai presus de întregul corp, iar prin rang este direct a doua după Cap... Acest Gât plăcut lui Dumnezeu și scânteind de dumnezeiescul Duh, singur mai presus de tot corpul, este mijlocitor și inel de legătură între Cap și Corp ${ }^{\prime 19}$. „De aici urmează că nici un membru nu poate să ajungă la împărtășirea puterii de viață care coboară din Cap, nici să se unească cu Capul altfel decât prin Gâtul dumnezeiesc, așa cum nu poate veni la Capul lui Hristos, la Dumnezeu și Tatăl, decât prin Hristos Capul nostru" ${ }^{20}$.

În cazul nostru al oamenilor, viața poate fi transmisă doar prin naștere, de aceea noi putem spune că în Biserică noi primim o altă naștere, ,"de sus”, intrând într-o altă viață, cea prin care suntem părtași, prin har, la viața lui Hristos. Dar Hristos este ascultare și noi nu putem intra în Viață, decât prin ascultare, de aceea și spunem că ascultarea este viață, iar neascultarea este moarte sau, mai bine zis, că ascultarea este adevărata fire a omului celui nou întru Hristos. Dar Hristos este în veci și om și Dumnezeu și El „își păstrează conștiința de Dumnezeu în pătimirea cu trupul și conștiința de om în săvârșirea lucrărilor dumnezeiești" ${ }^{21}$. Prin urmare, noi prin ascultare devenim părtași firii Lui dumnezeiești și astfel, ascultarea noastră aici pe pământ ne dăruiește o altă viață, prin care nu mai suntem străini și locuitori vremelnici, ci suntem împreună cetățeni cu sfinții și casnici ai lui Dumnezeu (Efeseni 2, 19). Dar acest lucru a devenit (și devine mereu) posibil doar prin ascultarea Maicii Domnului, prin răspunsul ei care ne-a deschis intrarea în Împărăție: Iată roaba Domnului, fie mie după cuvântul Tău!

\footnotetext{
${ }^{19}$ Teofan al Niceei, „,Tratat despre mărețiile negrăite ale Maicii Domnului și despre Taina Întrupării lui Dumnezeu cu binele ultim și cauza finală a tuturor existențelor", cap. X, în: diac. Ioan I. Ică jr., Maica Domnului în teologia secolului XX și în spiritualitatea isihastă a secolului XIV: Grigorie Palama, Nicolae Cabasila, Teofan al Niceei, Editura Deisis, Sibiu, 2008, p. 545.

${ }^{20}$ Teofan al Niceei, ,"Tratat despre mărețiile negrăite ale Maicii Domnului...", pp. 545-546.

${ }^{21}$ Pr. Dumitru Stăniloae, Chipul nemuritor..., p. 560.
} 